\title{
Pacemaker és ICD-infekciók. A diagnózistól a kezelésig
}

\author{
Benák Attila, Sághy László
}

\author{
SZTE ÁOK, II. sz. Belgyógyászati Klinika és Kardiológiai Központ, Szeged
}

Levelezési cím: Dr. Benák Attila, E-mail: office.in2nd@med.u-szeged.hu

\begin{abstract}
A kardiális implantált elektromos eszközök (CIED) infekciója az utóbbi időben egyre nagyobb számban beültetésre kerülő ICD és biventrikuláris készülékek miatt ugrásszerű növekedésnek indult. A fertőzések klinikai megjelenésük szerint lehetnek lokálisak, illetve szisztémásak. Mindkét típusban a patogén kórokozók döntően Staphylococcus speciesek, ami a baktérium speciális virulenciafaktoraival magyarázható. A diagnózis sokszor egyszerü: decubitus, fistula, lead vegetáció és hemokultúra pozitivitás. Bizonytalan esetekben a 18FDG-PET/CT-vizsgálat nyújt segítséget. Kezelésként a teljes rendszer eltávolítása javasolt, elsősorban transzvénás úton. Sebészi extrakció magas rizikójú betegek és nagyméretủ vegetációk kapcsán elsőként választandó. Prevencióként jelenleg a preoperatív antibiotikum-kezelés a bizonyítottan hatásos, széles körben alkalmazható eljárás. A resorbilis antibakteriális tasakok alkalmazása jelentheti a CIED-infekció kontroll jövőjét.
\end{abstract}

Kulcsszavak: CIED-infekció, Staphylococcus species, 18FDG-PET/CT, transzvénás lead extrakció, antibakteriális tasak

\section{Pacemaker and ICD infections: From diagnosis to treatment}

The cardiac implantable electronic devices (CIED) infections are increased in the past decade, due to the rising number of ICDs and biventricular devices. The infections can occur in local and systemic forms. The pathogen agents are the Staphylococcus species in the majority of cases, which can be explained by the special virulence factors. The diagnosis is simple in the following conditions: generator decubitus, fistule, lead vegetation with positive hemocultures. When the diagnosis is uncertain, 18FDG-PET/CT can help in the decision. In case of CIED infection, extraction of the complete system is recommended. Transvenous lead extraction should be the first choi$\mathrm{ce}$, except for high risk patient or massive lead vegetation. Preoperative antibiotic prophylaxis is the only proven method for prevention. The widespread usage of the absorbable antibacterial envelope can be the future of CIED infection control.

Keywords: CIED infections, Staphylococcus species, 18FDG-PET/CT, transvenous lead extraction, absorbable antibacterial envelope

\section{Bevezetö}

A kardiális implantált elektromos eszközök (CIED) száma a defibrillátor és reszinkronizációs terápia elterjedése óta folyamatos növekedésben van. Az egyre modernebb gyógyszeres és eszközös kezelésekkel a betegek élettartama növekszik, de az egyre komplexebb készülékek kibővült indikációs köre miatt ezen betegek egyre több komorbiditással is rendelkeznek. Többek között ezzel magyarázható, hogy CIED-fertőzésekben ugrásszerü, az implantációk számánál nagyobb arányú növekedés mutatkozott az elmúlt években. Ezen fertö- zések magas moratalitási rátája, valamint költséges kezelése mind egészségügyi, mind gazdasági szempontból nagy terhet jelent, ami miatt a fertőzések számának csökkentése a jelen és közeljövő sürgető feladata.

\section{Epidemiológia}

Az implantált eszközökkel kapcsolatos infekciók már a kezdetektöl leírásra kerültek, amelyek incidenciája különböző vizsgálatokban viszonylag széles spektrumon mozgott. Populáció alapú kohorsz vizsgálat alapján a 


\section{. TÁBLÁZAT. CIED-fertőzés rizikótényezői}

\begin{tabular}{|l|c|}
\hline & Odds ratio \\
\hline Korai reintervenció & 15 \\
\hline Kortikoszteroid kezelés & 14 \\
\hline Veseelégtelenség & 12 \\
\hline CRT-D vs. ICD/Pacemaker & 7,5 \\
\hline Láz <24 órával az implantáció előtt & 5,8 \\
\hline$>2$ elektróda jelenléte & 5,5 \\
\hline Generátorcsere & 3,7 \\
\hline Diabetes mellitus & 3,5 \\
\hline Orális antikoaguláns & 2,8 \\
\hline Ideiglenes pacemaker-elektróda & 2,5 \\
\hline
\end{tabular}

lokális zsebinfekció incidenciája 1,37/1000 eszköz-év, a véráramfertőzéssel járó CIED-infekciónál pedig 1,14/ 1000 eszköz-év (1).

$\mathrm{Az}$ ICD valamint reszinkronizációs terápia térhóditása óta a beültetett eszközök száma a 90'-es évek elejétöl a 2000-es évek végéig közel duplájára emelkedett. E mellett a CIED-infekciós ráta több mint háromszoros növekedést mutatott, amelynek föbb okai között megemlítendő a készüléket kapó betegek magasabb életkora, több társbetegsége, halmozódó generátorcserék és a fertőzést okozó kórokozók fokozódó rezisztenciája (2).

Számos infekciót fokozó rizikófaktor ismeretes, amelyek közül kiemelendő a korai reintervenció, és a tartós kortikoszteroid kezelése, valamint a krónikus veseelégtelenség és komplexebb eszköz (ICD, CRT-D) implantációja (1. táblázat). Nem elhanyagolható továbbá a generátorcsere, diabetes mellitus, antikoaguláns kezelés, ideiglenes pacemaker-terápia és az operátori tapasztalat fertőzésrizikóval való összefüggése $(3,4,5)$.

\section{Patogenezis}

A fertőzést az esetek 80-90\%-ában Staphylococcus species okozza, ezen belül is döntően koaguláz-negatív Staphylococcusok (60-70\%-ban S. epidermidis). A S. aureus által okozott CIED-infekciók 15-25\%-ban vannak jelen. Ezen felül kisebb arányban fordulnak elő Corynebacterium, Propionibacterium, Gram-negatív bacillusok és bizonyos gombafajok által okozott fertözések is (2) (1. ábra).

A Staphylococcusok dominanciájában döntő szerepe van a baktérium biofilmképző tulajdonságának. Ezen speciesek rendelkeznek specifikus adhezin molekulákkal, amelyek segítenek az eszközhöz való hozzátapadásban és az intercelluláris kapcsolatok kialakításában is. Ezen biofilmformátum ellenállóbbá teszi a baktériumokat mind az antibiotikumok, mind pedig a szervezet védekező mechanizmusaival szemben is. Továbbá az intercelluláris kapcsolatok révén a baktériumok egységesen működő génregulációja elősegíti az esetleges rezisztencia-mechanizmusok gyors elterjedését $(6,7)$. CIED-infekció leggyakrabban primer fertőződés kapcsán alakul ki. A bőr normálflórájában megtalálható baktériumok még a legszigorúbb sterilitási körülmények között is inokulálhatják a mütéti területet. Azt hogy későbbiekben mely esetekben lesz klinikailag manifesztálódó infekció azt a baktérium tulajdonságai és a korábban már említett rizikófaktorok együttesen fogják meghatározni. Jóval ritkább a másodlagos, hematogén szórás által az elektródákon megtapadó baktériumok okozta CIED-fertőzés.

\section{Diagnózis}

CIED-fertőzés klinikai megjelenés alapján két csoportra osztható, egyrészt szisztémás fertőzés jelei nélkül zajló lokális infekciókra, valamint szisztémás fertőzésekre (egyértelmű zsebinfekció jeleivel vagy a nélkül). Mindkét csoportban előfordulnak egyértelmü, illetve diagnosztikus nehézséget okozó esetek is.
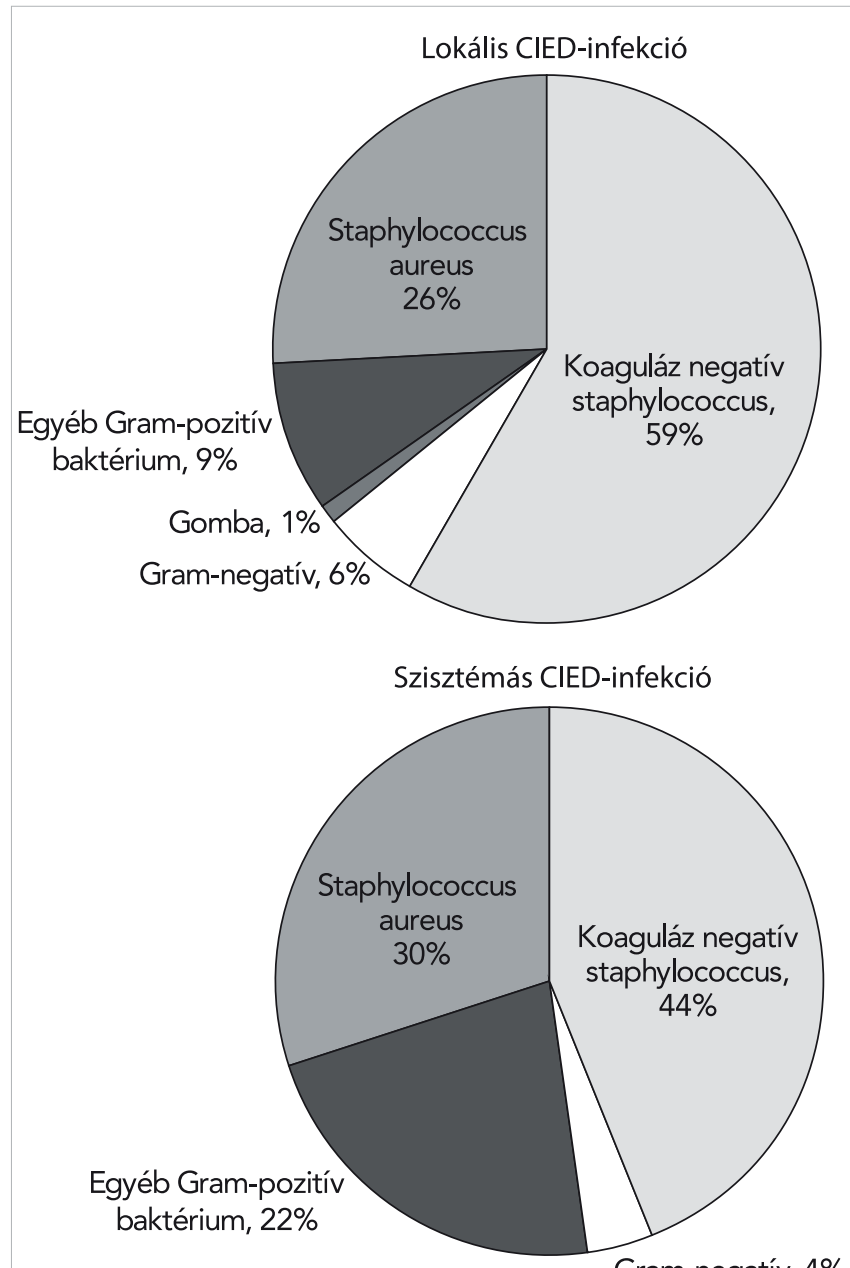

1. ÁBRA. Az SZTE ÁOK II. sz. Belgyógyászati Klinikán 2012 óta CIED-extrakción átesett betegek ( $n=122)$ patogén kórokozóinak eloszlása szisztémás és lokális fertőzésben 


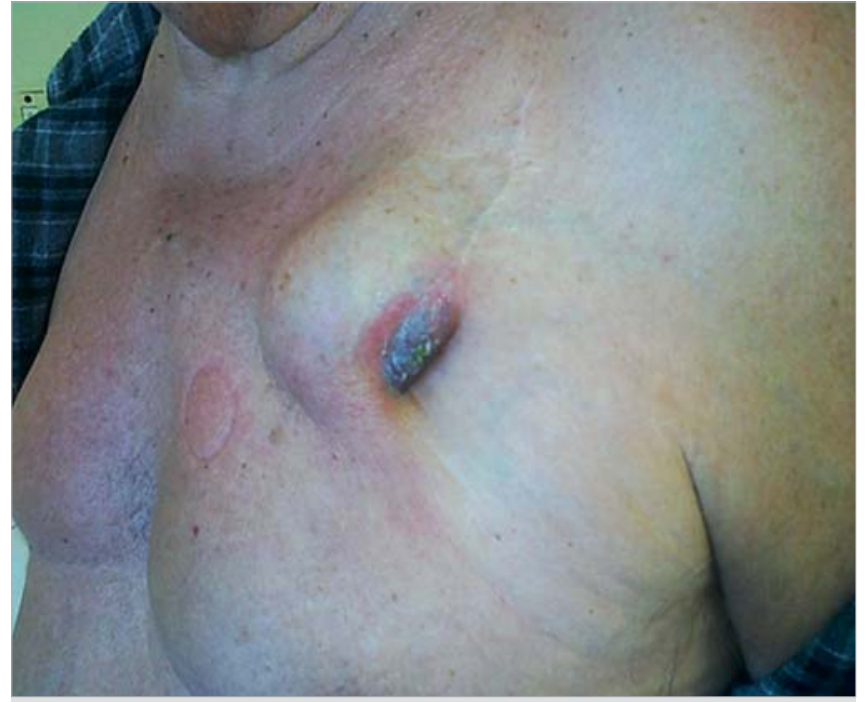

2. ÁBRA. ICD-generátor decubitus

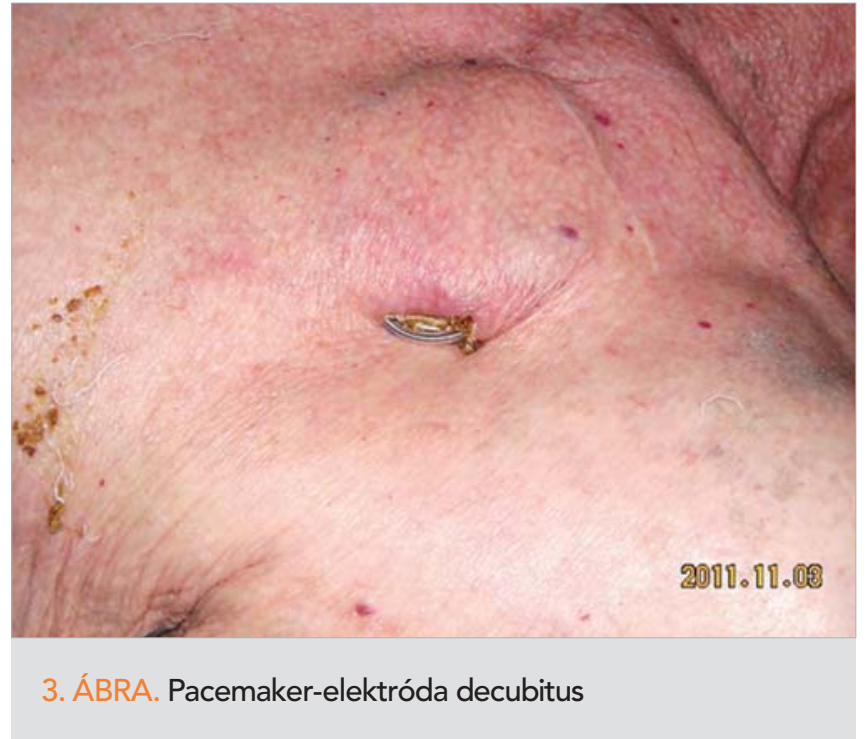

Lokális infekció járhat a beültetett eszköz decubitációjával, preeróziójával, a zseb sipolyjáraton keresztüli váladékozásával vagy tályogos folyamatával (2. ábra). Ezen egyértelmű esetek mellett gyakran előfordul a bőrgenerátorhoz történő fixáltsága, valamint - főleg generátorcserét követő - zsebduzzanat vagy erythemás bőrelváltozás, amelyhez szisztémás infekciós tünetek nem társulnak. Ezen megjelenési formákban a diagnózis felállítására sokszor csak szoros obszervációt követően, a klinikai kép függvényében kerül sor. Az utóbbi években kezdett elterjedni a CIED-infekciók kapcsán az 18FDG-PET/CT-vizsgálat, amely az előzőleg említett bizonytalan esetekben jó szenzitivitással és specificitással tudja elkülöníteni a bőrre lokalizált fertőzéseket a tényleges zsebinfekcióktól $(2,8,9)$.

A zsebinfekciók nagy része észlelésük idején még szisztémás tünetekkel nem jár. Ismeretlen eredetű viszszatérő lázas állapotok kapcsán azonban az implan- tált eszköz (ezen esetekben az elektróda/elektródák) fertőzésének kizárása feltétlenül szükséges (3. ábra). A diagnózis felállításában kulcsfontosságú a sorozatban vett hemokultúrák tenyésztési eredménye. Minden gyanús esetben javasolt transoesophageális echokardiográfia elvégzése, azonban az alacsony szenzitivitás és specificitás miatt ennek a vizsgálati eljárásnak a diagnosztikus értéke alacsony (4. ábra). A már említett 8FDG-PET/CT-vizsgálat ismeretlen eredetű láz, illetve CIED-infekció gyanú esetén is javasolt a diagnózis felállítására, azonban lead endocarditis kapcsán a szenzitivitás, illetve a reprodukálhatóság alacsonyabb a zsebre lokalizált fertőzésekkel összehasonlítva $(2,8,9)$.

\section{Kezelés}

CIED-infekció esetén a teljes rendszer eltávolítása javasolt, függetlenül attól, hogy lokális vagy szisztémás folyamatról van szó. Az implantált eszköz komplett extrakciója (5. ábra) javasolt továbbá okkult Staphylococcus bacteraemia, valamint billentyü endocarditis esetén, még akkor is, ha egyértelmü lead endocarditisre utaló jelek nincsenek (2). A mütéti radikalitás oka, hogy - a már említett bakteriális faktorok miatt - az elektródák szisztémás infekciós jelek hiányában is fertőzöttnek tekinthetőek. Ezt bizonyítja, hogy az elektródákról és a zsebből történő tenyésztések közel azonos arányban mutattak pozitivitást, valamint ezek bakteriális
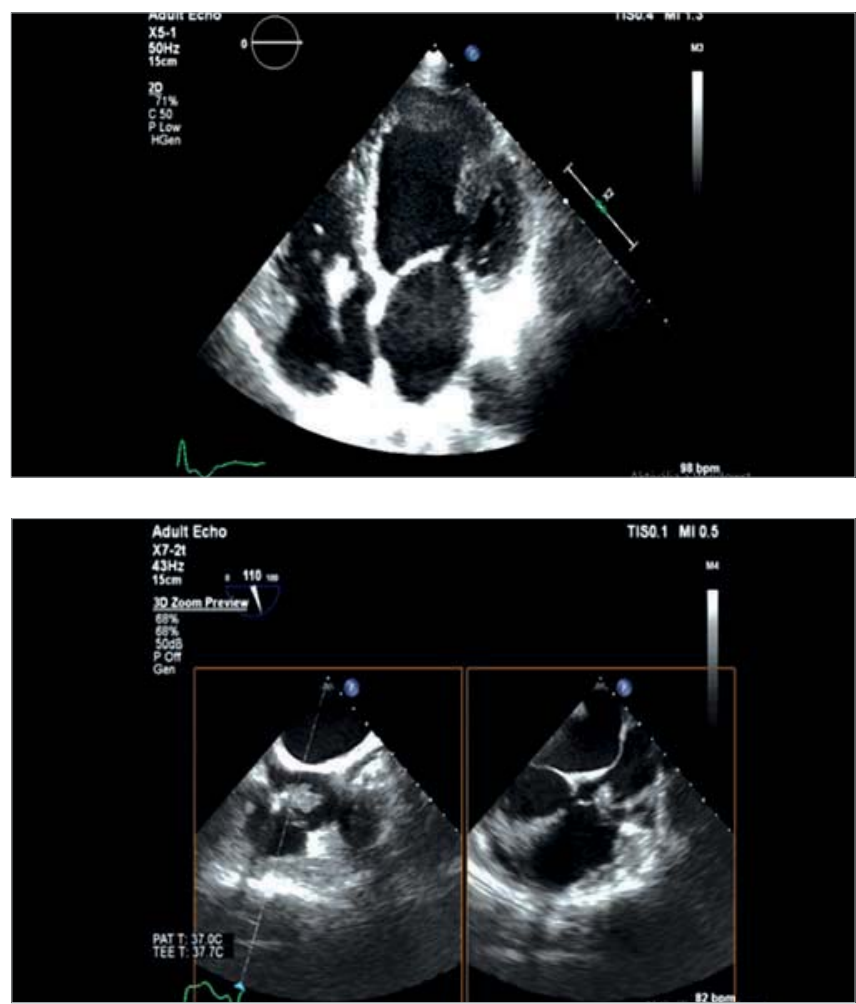

4. ÁBRA. Pacemaker-elektródán lévő vegetáció transthoracalis és transoesophagealis echokardiográfiás képe 


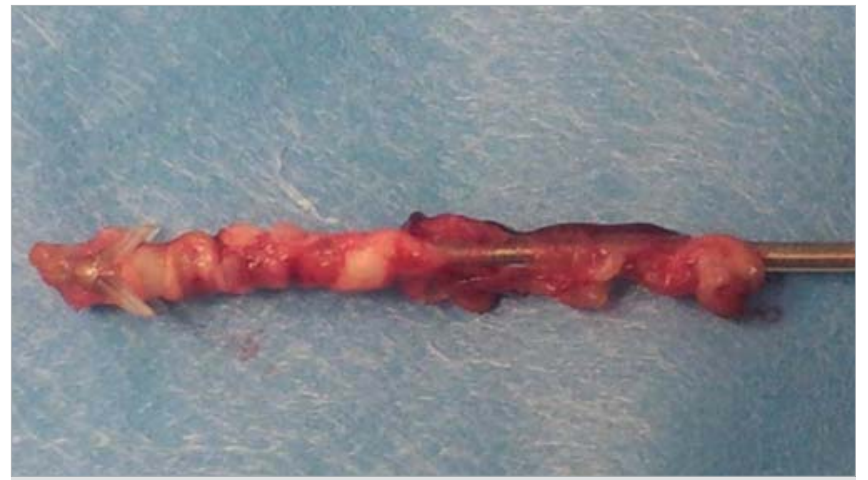

5. ÁBRA. Passzív fixációs kamrai elektróda transzvénás lead extrakció után

spektruma jól korrelál egymással $(10,11)$. Számos vizsgálat bizonyította a konzervatív terápia hatástalanságát, amelynek föbb okai között említendő az antibiotikumok alacsony szöveti penetranciája, a pacemakerzseb izolált volta, valamint a kórokozók védekező mechanizmusai. Intermittáló antibiotikum-kezeléssel szinte minden esetben relapszus várható, de élethosszan tartó antimikrobális kezeléssel is 7,3\%-ban az infekció progressziójára lehet számítani. Ezzel szemben a teljes extrakcióval 96-98\%-ban teljes gyógyulás érhető el (10-14). Elsődlegesen választandó eljárás a transzvénás úton történő eltávolítás (TLE), amelynek elvégzése csak gyakorlott centrumokban ajánlott, ahol megfelelő eszközös és szívsebészeti háttér biztosított. Elöbbi magában foglalja az elektródák merevítésére szolgáló locking styletet, valamint az elektróda felszabadítására használható aktív energiaközlő (elsősorban lézer) vagy mechanikus elven müködő extrakciós eszközöket. Nagyszámú TLE-n átesett betegpopulációt feldolgozó közleményekben 3,6-5,1\% minor szövődményarány mellett 0,2-1,8\%-ban fordult elő major komplikáció, ellentétben a szívsebészeti eljárásokkal, ahol az átlagos műtéti mortalitás lényegesen magasabb (15-18).

Szívsebészeti műtét választandó korábbi sikertelen extrakció, illetve szignifikáns méretű remnant eltávolítására, valamint $2 \mathrm{~cm}$-nél nagyobb vegetáció esetén. Ezen felül számos tényező figyelembe vétele szükséges a primer mütéti típus megválasztása előtt, többek között az elektródák száma és életkora, a beteg általános állapota és társbetegségségei, valamint egyéb olyan faktorok, amelyek a transzvénás úton történő eltávolítást mütéttechnikailag komplikálttá teszik (elektródák lefutása, korábbi extrakciós kísérlet, csonkolt elektródák vagy dual-coil sokk-elektróda jelenléte stb.).

\section{Prevenció}

Az emelkedő infekciós ráta és az ezzel járó magas mortalitás a fertőzések megelőzésére fokozott hangsúlyt helyez. A műtétek során alkalmazott aszeptikus technika és sterilitási szabályok betartása alapvető követelmény. Törekedni kell továbbá a zsebhaematoma elkerülésére, amelynek redukciójában fontos az antikoagulált betegek esetében a perioperatív heparin kezelés elkerülése. A beavatkozás előtt egy órával alkalmazott intravénás cefazolin/vancomycin infekciót csökkentő hatását randomizált, kontrollált kettős vak vizsgálat támasztotta alá (19). Ezzel szemben a zseb povidon-jodiddal (Betadine) vagy antibiotikummal történő irrigációja, valamint posztoperatív antibiotikum-kezelés nem csökkenti szignifikánsan a CIED-fertőzés incidenciáját $(20,21)$. A preventív antibiotikum-kezelés időtartamáról szóló vizsgálatok és konszenzusok ellentmondásosak, egyértelmű ajánlás ezen területen nem fogalmazódott meg. Ugyancsak kérdéses a műtéti terület izolálására használt antiszeptikum választása is. A REPLACE-regiszter a povidin-jodid esetében magasabb infekciós rátát mutatott a chlorhexidinnel szemben, viszont egy friss, nagy esetszámú obszervációs vizsgálat nem mutatott különbséget a két csoport között $(22,23)$.

A legföbb probléma az antibiotikumok alacsony szöveti penetranciája, amelynek föleg a generátor körül kialakult fibrotikus tok szab gátat. Másrészről a koaguláz negatív staphylococcusok jelentős hányada cefazolinra rezisztenciát mutatnak. Tekintettel ezen speciális helyzetre, kifejlesztésre kerültek resorbilis, antibiotikum kombinációval (minocyclin és rifampicin) bevont tasakok, amelyeket alkalmazva a megfelelő helyen, a megfelelő időtartamra lehet biztosítani effektív koncentrációban, széles bakteriális spektrumot lefedő antibiotikum-hatást. Több retrospektív tanulmányt követően már prospektív randomizált vizsgálat is alátámasztotta ezen preventív eljárás infekciót csökkentő hatását (24).

\section{Következtetések}

A pacemaker valamint defibrillátor-beültetések számának fokozatos emelkedésével egyre több esetben kell számolni ezen rendszerek fertőzésével. Figyelembe véve a jelen tendenciáit, a fertőzések arányának növekedése meg fogja haladni az implantációs számok növekedéséből elméletileg várható arányt. Tekintve a már kialakult fertőzések kezelési nehézségeit és költséges voltát, a primer prevencióra fokozott hangsúly helyeződik. Ebben föleg a magas rizikójú betegek körében alkalmazandó új infekciókontroll-stratégiák létrehozása és az antibakteriális tasakok széles körü elterjedése hozhat elörelépést.

A diagnosztika tekintetében az egyre szélesebb körben alkalmazott PET/CT nagy segítséget tud nyújtani a nem egyértelmű, diagnosztikus kihívást jelentő esetekben.

A már kialakult fertőzés kezelése - a transzvénás úton történő eltávolítás dinamikusan fejlődő eszköztárával és specializálódott centrumok tapasztalatának növekedésével - egyre hatékonyabban és biztonságosabban kivitelezhető. 


\section{Irodalom}

1. Uslan DZ, Sohail MR, St Sauver JL, Friedman PA, Hayes DL, et al. Permanent pacemaker and implantable cardioverter-defibrillator infection: a population-based study. Arch Intern Med 2007;c167:c669-675. DOI: 10.1001/archinte.167.7.669

2. Larry M. Baddour, Andrew E. Epstein, Christopher C. Erickson, Bradley P. Knight, Matthew E. Update on Cardiovascular Implantable Electronic Device Infections and Their Management: A Scientific Statement From the American Heart Association. Circulation 2010; 121: 458-477, DOI: 10.1161/CIRCULATIONAHA.109.192665

3. Sohail MR, Uslan DZ, Khan AH, Friedman PA, Hayes DL, et al. Risk factor analysis of permanent pacemaker infection. Clin Infect Dis 2007; 45: 166-173. DOI: $10.1086 / 518889$

4. Klug D, Balde M, Pavin D, Hidden-Lucet F, Clementy J, et al. PEOPLE Study Group. Risk factors related to infections of implanted pacemakers and cardioverter-defibrillators: results of a large prospective study. Circulation 2007; 116: 1349-1355. DOI: 10.1161/ CIRCULATIONAHA.106.678664

5. Lekkerkerker JC, van Nieuwkoop C, Trines SA, van der Bom JG, Bernards A, et al. Risk factors and time delay associated with cardiac device infections: Leiden device registry. Heart 2009; 95: 715720. DOI:10.1136/hrt.2008.151985

6. Maria Grazia Bongiorni, Carlo Tascini, Enrico Tagliaferri, Andrea Di Cori, Ezio Soldati, et al. Microbiology of cardiac implantable electronic device infections. Europace 2012; 14: 1334-1339, DOI:10.1093/europace/eus044

7. Christine Heilmann, Oliver Schweitzer, Christiane Gerke, Nongnuch Vanittanakom, Dietrich Mack2, Friedrich Gotz. Molecular basis of intercellular adhesion in the biofilm-forming Staphylococcus epidermidis. Molecular Microbiology 1996; 20(5): 1083-1091.

8. Vaidyanathan SA, Patel CN, Scarsbrook AF, Chowdhury FU. FDG $\mathrm{PET} / \mathrm{CT}$ in infection and inflammation current and emerging clinical applications. Clinical Radiology 2015; 70: 787e800. DOI: 10.1016/j. crad.2015.03.010

9. Cherie Millar B, Bernard D. Prendergast, Abass Alavi, John E. Moore. 18FDG-positron emission tomography (PET) has a role to play in the diagnosis and therapy of infective endocarditis and cardiac device infection. International Journal of Cardiology 2013; 167 : 1724-1736. DOI: 10.1016/j.ijcard.2012.12.005

10. Chua JD, Wilkoff BL, Lee I, Juratli N, Longworth DL, Gordon SM. Diagnosis and management of infections involving implantable electrophysiologic cardiac devices. Ann Intern Med 2000; 133: 604-608. 10.7326/0003-4819-133-8-200010170-00011

11. Sohail MR, Uslan DZ, Khan AH, Friedman PA, Hayes DL, et al. Infective endocarditis complicating permanent pacemaker and implantable cardioverterdefibrillator infection. Mayo Clin Proceed 2008; 83: 46-53. DOI: 10.4065/83.1.46

12. Molina JE. Undertreatment and overtreatment of patients with infected antiarrhythmic implantable devices. Ann Thorac Surg 1997; 63: 504-509. DOI: 10.1016/S0003-4975(96)01033-8

13. del Rio A, Anguera I, Miró JM, Mont L, Fowler VG Jr, et al. Hospital Clinic Endocarditis Study Group. Surgical treatment of pacemaker and defibrillator lead endocarditis: the impact of electrode lead extraction on outcome. Chest 2003; 124: 1451-1459. DOI: 10.1378/ chest.124.4.1451

14. Baddour LM. Infectious Diseases Society of America's Emerging Infections Network. Long-term suppressive antimicrobial therapy for intravascular device-related infections. Am J Med Sci 2001; 322 : 209-212. DOI: 10.1097/00000441-200110000-00011

15. Luca Bontempi MD, Francesca Vassanelli MD, Manuel Cerini MD, Lorenza Inama MD, Francesca SalghettiMD, et al. Predicting the difficulty of a transvenous lead extraction procedure: Validation of the LED index. J Cardiovasc Electrophysiol 2017; 1-8. DOI: $10.1111 /$ jce. 13223

16. Oussama Wazni, Laurence M. Epstein, Roger G. Carrillo, Charles Love, Stuart W. Adler, David W. Riggio, et al. Lead Extraction in the Contemporary Setting: The LExICon Study. An Observational Retrospective Study of Consecutive Laser Lead Extractions. Journal of the American College of Cardiology 2010; 55(6): DOI:10.1016/j.jacc.2009.08.070

17. Maria Grazia Bongiorni, Ezio Soldati, Giulio Zucchelli, Andrea Di Cori, Luca Segreti, et al. Transvenous removal of pacing and implantable cardiac defibrillating leads using single sheath mechanical dilatation and multiple venous approaches: high success rate and safety in more than 2000 leads. European Heart Journal 2008; 29: 2886-2893. DOI:10.1093/eurheartj/ehn461

18. Michael P. Brunner, Edmond M. Cronin, Valeria E. Duarte, Changhong Yu, Khaldoun G. Tarakji, et al. Clinical predictors of adverse patient outcomes in an experience of more than 5000 chronic endovascular pacemaker and defibrillator lead extractions. Heart Rhythm2014; 11: 799-805. DOI: 10.1016/j.hrthm.2014.01.016 19. de Oliveira JC, Martinelli M, D'Orio Nishioka SA, Varejão T, Uipe D, et al. Efficacy of antibiotic prophylaxis before the implantation of pacemakers and cardioverter defibrillators: results of a large, prospective, randomized double blinded, placebo-controlled trial. Circ Arrhythm Electrophysiol 2009; 2: 29-34. DOI: 10.1161/CIRCEP.108.795906

20. Lakkireddy D, Valasareddi S, Ryschon K, Basarkodu K, Rovang $\mathrm{K}$, Mohiuddin SM, et al. The impact of povidone-iodine pocket irrigation use on pacemaker and defibrillator infections. Pacing Clin Electrophysiol 2005; 28: 789-94. DOI: 10.1111/j.1540-8159.2005.00173.x 21. Khalighi K, Aung TT, Elmi F. The role of prophylaxis topical antibiotics in cardiac device implantation. Pacing Clin Electrophysiol 2014; 37: 304-11. DOI: 10.1111/pace.12280

22. Uslan DZ, Gleva MJ, Warren DK, Mela T, Chung MK, Gottipaty $\mathrm{V}$, et al. Cardiovascular implantable electronic device replacement infections and prevention: results from the REPLACE registry. Pacing Clin Electrophysiol 2012; 35: 81-7. DOI: 10.1111/j.1540-8159.2011.03257.x

23. Qintar M, Zardkoohi O, Hammadah M, Hsu A, Wazni O, Wilkoff $B L$, et al. The impact of changing antiseptic skin preparation agent used for cardiac implantable electronic device (CIED) procedures on the risk of infection. Pacing Clin Electrophysiol 2015; 38: 240-6. DOI: $10.1111 /$ pace.12514

24. Khaldoun G. Tarakji, MPH, Suneet Mittal, Charles Kennergren, Ralph Corey, Jeanne Poole, Kurt Stromberg, et al. Worldwide Randomized Antibiotic EnveloPe Infection PrevenTion Trial (WRAP-IT). Am Heart J 2016; 180: 12-21. DOI: 10.1016/j.ahj.2016.06.010 